\title{
Strategy to Maintain Hading-Hoba Mulung in Capture Fisheries Activities In Pantar Barat District, Alor Regency
}

\author{
Luthfiah Usman ${ }^{1}$, Achmar Mallawa ${ }^{2}$, Mardiana Ethrawaty Fachry ${ }^{2}$ \\ ${ }^{1}$ Master Program, Postgraduet School, Hasanuddin University, Makassar, Indonesia \\ ${ }^{2}$ Faculty of Marine Sciences and Fisheries, Hasanuddin University, Makassar, Indonesia \\ DOI: 10.29322/IJSRP.11.09.2021.p11739 \\ http://dx.doi.org/10.29322/IJSRP.11.09.2021.p11739
}

\begin{abstract}
One form of local wisdom in the management of natural resources in coastal and marine areas that is still running today in Alor Regency is Mulung in the customary area of the Baranusa Kingdom, West Pantar District, which had been lost for decades. Mulung is a local wisdom of the Baranusa community in the form of a system of regulating the use of marine resources on a regular basis with the aim of maintaining the sustainability and sustainability of marine resources within a certain period of time agreed by the Customary Council and the King. The research has been carried out from January to March 2021. The aim is to analyze the strategy to maintain the existence of Hading-Hoba Mulung in Alor Regency. The research method is a qualitative descriptive survey and SWOT analysis. The results showed. Strategies to maintain the Hading-Hoba Mulung regulations in Alor Regency include: (1) Strengthening the Hading-Hoba Mulung customary institutions, (2) Development of fishing technology, (3) Development of fishery support facilities (TPI, Ice Factory) and access to marketing, (4) Community empowerment through socialization/extension on fisheries related to customary and government regulations, (5) Strengthening supervision activities by traditional institutions and the government in the Mulung area.
\end{abstract}

Index Terms- Hading-Hoba Mulung, capture fisheries, strategy.

\section{INTRODUCTION}

$\mathrm{M}$ anagement of fishery resources involving community institutions is a process of giving authority, responsibility and opportunity to the community to manage their fishery resources by first defining their needs and desires, goals and aspirations [1]. One form of fishery management that involves community institutions, namely through the value of local wisdom or better known as the customary rights of the sea, is used by the community to survive in an environment that is integrated with the belief system, norms, culture that are expressed in the traditions adopted for a period of time. which is old.

Alor Regency has the potential to develop marine fisheries with capture fisheries production of 0.41 percent from 2017 with a total of 9,398 tons to 9,437.3 tons in 2018. Meanwhile, aquaculture increased 58.66 percent from 348.1 tons to 551.5 tons. tons in 2018. Besides the potential for fisheries, clusters of large and small islands as well as the natural beauty of the underwater world have the potential to be developed as marine tourism objects $[2]$.

One form of local wisdom in the management of coastal and marine natural resources that is still running today in Alor Regency is Mulung in the ulayat area of the Baranusa Kingdom, West Pantar District. Mulung comes from the local language Baranusa which means prohibition. Mulung is a local wisdom of the local community in the form of a system for regulating the use of marine resources on a regular basis with the aim of maintaining the sustainability and sustainability of marine resources within a certain period of time agreed by the Customary Council and the King. In the past, the Customary Council and the King agreed to manage the territorial waters by carrying out the Hading Mulung (closing the prohibited area) and Hoba Mulung (opening the prohibited area) stages. The marine resources agreed to be managed with Mulung include clams, snails, lola, sea cucumbers, reef fish and pelagic fish. Along with the times, the Mulung tradition has begun to fade and even disappear. So far, there have been three implementations of Mulung. The first was during the royal era until around the 1970s until 1977. The level of community compliance with this regulation was quite high. The local community also believes that natural law will apply to anyone who violates the Mulung rules, namely the violators will be eaten by crocodiles [3]. Second, in the 1990s, community compliance began to weaken and Mulung was no longer implemented and obeyed by the people of Baranusa. One of the causes is the factor of people's food needs which continue to increase due to population growth. The modernization of mindset is also the cause of people starting to leave traditional cultural traditions. The loss of the order of the customary council is due to the migration of the population so that there is no longer regeneration of the customary council and the weakness of supervision. Some of these factors tend to have the potential to weaken and even eliminate Mulung's local wisdom. Third, on 31 October 2016 Mulung was revived by the Customary Council and the King after more than 20 years of not being enforced.

This study aims to analyze the strategy of maintaining the Hading-Hoba Mulung rules in capture fisheries activities in the West Pantar District of Alor Regency in order to maintain the sustainability of fishery resources in Alor Regency. The benefits of the research are (1) As input for policy makers in terms of setting policies on the management and utilization of fishery 
resources in Baranusa waters, (2) as reference material for other researchers.

\section{DATA AND METHODS}

A. Time and Place

The study was carried out from January to March 2021 in the waters of Baranusa, West Pantar District, Alor Regency, East Nusa Tenggara Province.

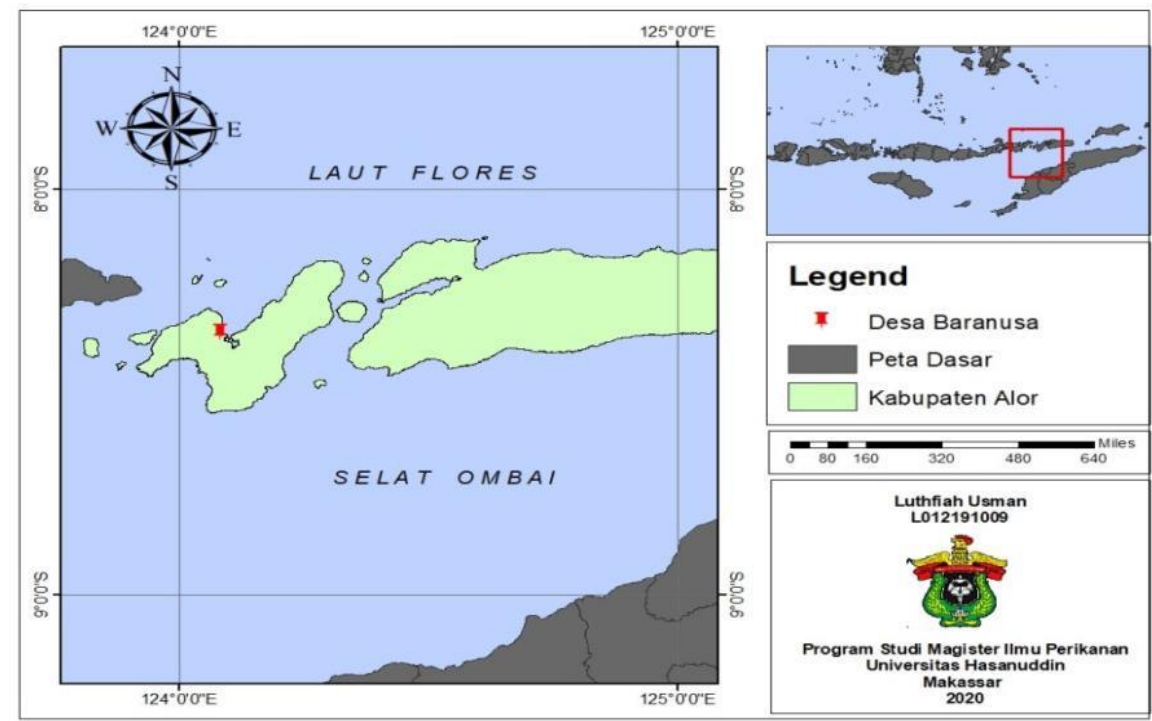

Figure 1. Research location

The equipment needed in the research and its uses are presented in

\section{B. Research Equipment}

Table 1.

Table 1. Research tools and their uses

\begin{tabular}{ll}
\hline Tools & Use \\
\hline Stationery & Used to record data and interview results obtained \\
Camera & Used as a tool for documenting activities. \\
Questionnaire & Used as a guide to obtain additional information needed from fishermen. \\
Tape Recorder & Used to record during the interview \\
\hline
\end{tabular}

\section{Data Collection}

The research method is using a survey method by means of direct interviews. The survey method was carried out to obtain data about existing facts and to find factual information that occurred at the research location.
The types of data, data sources, and retrieval methods are presented in Table 2 below:

Table 2. Types of Data, Data Sources, and Data Retrieval Methods

\begin{tabular}{|c|c|c|c|}
\hline Research purposes & Data Type & Retrieval Method & Data source \\
\hline $\begin{array}{l}\text { Determine policy } \\
\text { strategy to maintain the } \\
\text { existence of Hading- } \\
\text { Hoba Mulung }\end{array}$ & $\begin{array}{l}\text { Primary : } \\
\text { Internal factors are Strengths and } \\
\text { Weaknesses. } \\
\text { External Factors } \\
\text { Opportunity (Opportunity) and } \\
\text { Threat (Thread) }\end{array}$ & $\begin{array}{l}\text { Direct observation } \\
\text { and interview }\end{array}$ & $\begin{array}{l}\text { Customary councils, } \\
\text { fishermen, community } \\
\text { leaders who understand } \\
\text { local wisdom at the } \\
\text { research site }\end{array}$ \\
\hline
\end{tabular}

\section{Data Analysis}

This publication is licensed under Creative Commons Attribution CC BY.
To determine the policy strategy in an effort to maintain the existence of Hading Hoba Mulung, the following analysis is carried out: 


\section{SWOT analysis}

SWOT analysis is used with the aim of systematically identifying various factors to formulate a development policy strategy to maintain Hading-Hoba Mulung in Alor Regency. The stages of the SWOT analysis procedure are carried out through the following stages: 1). Determine internal factors (strengths and weaknesses) and external (opportunities and threats) 2). Determine the weight and rating on each internal factor and external factor. 3). Determine the weighted score by multiplying the weight value $x$ rating. 4). Develop an Internal Strategic Factors Analysis Summary (IFAS) matrix and an External Strategic Factors Analysis Summary (EFAS) matrix. 5). Draw up a SWOT diagram. 6). Develop a SWOT matrix [4].

\section{RESULTS AND DISCUSSION}

\section{Strategy to defend Hading-Hoba Mulung}

As a strategy to maintain the existence of Hading-Hoba Mulung rules for sustainable fisheries, researchers tried to develop strategies using SWOT analysis, based on information obtained during the study, several parameters emerged that were used to determine internal and external factors. The internal factors in question are factors that directly affect the traditional rules of Hading-Hoba Mulung which consist of Strengths and Weaknesses, while external factors are from outside such as the environment that also influence the activities of Hading-Hoba Mulung which consists of Opportunities ( Opportunity) and Threats (Threat).

\section{Evaluation of Internal Strategic Factors}

The results of the analysis obtained several main internal factors that can be used as strengths and weaknesses of the Hading-Hoba Mulung rule in Baranusa, presented in table 3 below:

Table 3. Assessment of the Strengths and Weaknesses of the Hading-Hoba Mulung rule in Pantar Barat District, Alor Regency.

\begin{tabular}{|c|c|c|c|}
\hline NO & Key Parameters & Indicator & $\mathrm{S} / \mathrm{W}$ \\
\hline 1 & $\begin{array}{l}\text { Has the customary rules of Hading- } \\
\text { Hoba Mulung }\end{array}$ & $\begin{array}{l}\text { Hading-Hoba Mulung regulates the management of marine } \\
\text { resources in Baranusa in terms of fishing which is binding on } \\
\text { the entire community so that it is always obeyed, if there are } \\
\text { violations, sanctions will be imposed. }\end{array}$ & S1 \\
\hline 2 & $\begin{array}{l}\text { Fishing activity in general is still } \\
\text { profitable. }\end{array}$ & $\begin{array}{l}\text { Fishermen's catches are sold fresh in local markets and some } \\
\text { are dried for later resale. }\end{array}$ & S2 \\
\hline 3 & Fisherman experience & $\begin{array}{l}\text { Most of the respondents have } 10-20 \text { years of experience as } \\
\text { fishermen. }\end{array}$ & S3 \\
\hline 4 & $\begin{array}{l}\text { The abundance of high economic } \\
\text { fish resources in the Mulung area. }\end{array}$ & $\begin{array}{l}\text { The improving condition of coral reefs is directly proportional } \\
\text { to the availability of high economic fish resources in the } \\
\text { Mulung area. }\end{array}$ & S4 \\
\hline 5 & $\begin{array}{l}\text { Fishing gear technology and fishing } \\
\text { business }\end{array}$ & $\begin{array}{l}\text { Knowledge of fishermen related to fishing gear used for } \\
\text { generations, the operation method is relatively simple so that } \\
\text { the catch is only modest. }\end{array}$ & W1 \\
\hline 6 & $\begin{array}{l}\text { Limited access to marketing/sales of } \\
\text { catch }\end{array}$ & $\begin{array}{l}\text { The absence of the nearest Fish Auction Place (TPI) has been } \\
\text { planned by the government but has not been realized. This } \\
\text { condition causes fishermen to only sell their catch in the local } \\
\text { market or to collectors in Baranusa. }\end{array}$ & W2 \\
\hline 7 & Fishing business support facilities & $\begin{array}{l}\text { Limited supporting facilities such as TPI and ice factory (due } \\
\text { to electricity conditions in the research location only } 12 \text { hours, } \\
\text { starting from } 18.00 \text { to } 06.00 \text { ). so that the catch does not last } \\
\text { long if fishermen want to sell outside the island of Baranusa. }\end{array}$ & W3 \\
\hline 8 & $\begin{array}{l}\text { Weak institutional oversight of the } \\
\text { Baranusa indigenous peoples and } \\
\text { the government }\end{array}$ & $\begin{array}{l}\text { Almost all respondents said that there was a lack of attention } \\
\text { from traditional institutions and the government in terms of } \\
\text { carrying out supervision in the Hading-Hoba Mulung area. As } \\
\text { a result, fishermen from outside carry out fishing activities in } \\
\text { the area. }\end{array}$ & W4 \\
\hline 9 & $\begin{array}{l}\text { Lack of socialization/counseling on } \\
\text { fishing for fishermen. }\end{array}$ & $\begin{array}{l}\text { There are still fishermen from Baranusa who use fishing gear } \\
\text { that is not environmentally friendly. }\end{array}$ & W5 \\
\hline 10 & $\begin{array}{l}\text { The emergence of conflict between } \\
\text { fishermen }\end{array}$ & $\begin{array}{l}\text { There is no firm action from traditional institutions related to } \\
\text { fishermen using bomb and potassium fishing gear. Because } \\
\text { they have a family relationship, they are reluctant to } \\
\text { reprimand them. }\end{array}$ & W6 \\
\hline
\end{tabular}

Description: $S=$ Strength (Strength), $W=$ Weakness (Weakness)

\section{Evaluation of External Strategic Factors}


He explained several external factors that directly or indirectly influenced the Hading-Hoba Mulung customary rules. External factors that have a positive effect are opportunities and negative effects are threats, which are presented in table 4 below:

Table 4. Assessment of opportunities and threats of the Hading-Hoba Mulung current in Pantar Barat District, Alor Regency.

\begin{tabular}{|c|c|c|c|}
\hline No & Key Parameters & Indicator & $\mathrm{O} / \mathrm{T}$ \\
\hline 1 & Potential fish resources owned & $\begin{array}{l}\text { The Hading-Hoba Mulung rule is an effort to provide } \\
\text { opportunities for marine biota to grow and develop so that their } \\
\text { availability is always there and abundant. Respondents felt that } \\
\text { they had benefited greatly after the Hading-Hoba Mulung } \\
\text { regulation was re-enacted. }\end{array}$ & $\mathrm{O} 1$ \\
\hline 2 & The market potential is quite large & $\begin{array}{l}\text { The catches of fishermen are not only sold fresh, they can also } \\
\text { be processed into packaged products with a higher selling } \\
\text { value. In addition, the research location has the potential for } \\
\text { marine tourism because of its beauty and is used as an } \\
\text { educational tour about local wisdom in marine management. }\end{array}$ & $\mathrm{O} 2$ \\
\hline 3 & $\begin{array}{l}\text { There are government policies that } \\
\text { support }\end{array}$ & $\begin{array}{l}\text { In the Decree of the Minister of Maritime Affairs and Fisheries } \\
\text { Number } 35 \text { of } 2016 \text { making the Pantar Strait a Swaka Alam } \\
\text { Perairs (SAP) with an area of } 276,693.38 \text { Ha with the aim of } \\
\text { regional sustainable development: protection and management } \\
\text { of coral reef ecosystems, seagrass beds, mangroves, sustainable } \\
\text { fisheries, and protected marine biota such as turtles, sharks, } \\
\text { manta rays, and marine mammals including whales, dolphins, } \\
\text { and dugongs as well as sustainable development and use. }\end{array}$ & $\mathrm{O} 3$ \\
\hline 4 & Bad weather or climate & $\begin{array}{l}\text { The level of rainfall in Alor Regency is low, because the rainy } \\
\text { season is shorter, from November to March and there are } \\
\text { frequent storms and waves, compared to the dry season from } \\
\text { April to October. Fishermen carry out fishing activities for } 7 \\
\text { months, but according to Hoba Mulung's time, they only carry } \\
\text { out fishing activities for } 3 \text { months in the Mulung area, the rest } \\
\text { operate outside the Mulung area. }\end{array}$ & $\mathrm{T} 1$ \\
\hline 5 & $\begin{array}{l}\text { Destructive fishing activities } \\
\text { (destructive and illegal fishing) }\end{array}$ & $\begin{array}{l}\text { The use of destructive fishing gear causes damage to the coral } \\
\text { reef ecosystem so that fish resources are reduced, this activity } \\
\text { is carried out by fishermen from outside Baranusa. }\end{array}$ & $\mathrm{T} 2$ \\
\hline
\end{tabular}

Description: $O=$ Opportunities (Opportunities), $T=$ Threats $($ Threats)

\section{Assessment of Internal and External Factors}

To see the influence of internal and external factors on the Hading-Hoba Mulung rules in fishing activities at the research location, the internal factors analysis summary (IFAS) matrix model and the external factors analysis summary (EFAS) matrix were used.

From the results of the IFAS calculation, it shows that the main strength is (S1) the existence of the Hading-Hoba Mulung rule of 0.75 ; (S4) the availability of abundant marine resources is 0.75 ; (S2) fishing activity is profitable by 0.40 ; and $(\mathrm{S} 3)$ the average respondent fisherman has more than 10 years of fishing experience at 0.40 . While the main weaknesses are (W6) the emergence of conflicts between fishermen of 0.38 ; (W1) the weakness of the fishing technology used is 0.25 ; (W5) lack of socialization/counseling on the rules of Hading-Hoba Mulung by 0.20; (W4) the weak supervision of Baranusa traditional institutions by 0.15 ; (W2) weak access to marketing by 0.08 ; (W3) Weak fisheries support facilities. To be more clearly presented in table 5 below: 
Table 5. Assessment of Internal Factors Analysis Summary.

\begin{tabular}{|c|c|c|c|c|c|}
\hline \multicolumn{2}{|c|}{ Strategic Factor } & \multirow{2}{*}{$\begin{array}{l}\text { Weight } \\
0,15\end{array}$} & \multirow{2}{*}{$\begin{array}{l}\text { Rating } \\
5\end{array}$} & \\
\hline \multirow{4}{*}{ Strenght } & Have the Hading-Hoba Mulung customary rules (S1) & & & 0,75 & \\
\hline & Fishing activity is still profitable (S2) & 0,1 & 4 & 0,40 & \\
\hline & Fisherman experience (S3) & 0,1 & 4 & 0,40 & \\
\hline & $\begin{array}{l}\text { Abundance of high economic fish resources in the Mulung area } \\
\text { (S4) }\end{array}$ & 0,15 & 5 & 0,75 & \\
\hline \multicolumn{2}{|c|}{ Total Strength } & & & & 2,30 \\
\hline \multirow{6}{*}{ Weakness } & Technology of fishing gear and fishery business (W1) & 0,1 & 2,5 & 0,25 & \\
\hline & Limited access to marketing/sales of catch (W2) & 0,05 & 1,5 & 0,08 & \\
\hline & Fishing business support facilities (W3) & 0,05 & 1 & 0,05 & \\
\hline & $\begin{array}{l}\text { Weak institutional supervision of the Baranusa indigenous people } \\
\text { (W4) }\end{array}$ & 0,05 & 2,9 & 0,15 & \\
\hline & Lack of socialization/counseling on fishing for fishermen (W5) & 0,1 & 2 & 0,20 & \\
\hline & Conflict between fishermen (W6) & 0,15 & 2,5 & 0,38 & \\
\hline \multicolumn{2}{|c|}{ Total Weakness } & & & & $\mathbf{1 , 1 0}$ \\
\hline & TOTAL & 1 & & & 3,40 \\
\hline
\end{tabular}

Rating description: 1: very weak, 2: weak, 3: moderately strong, 4: strong, 5: very strong

Based on the value of IFAS analysis, it is known that the Hading-Hoba Mulung policy/rule in fishing activities has a score of 3.40 2.5, meaning that internal conditions have the strength to overcome a situation of weakness. The condition of the Hading-Hobang Mulung regulation has many weaknesses that must be overcome in order to seize opportunities by utilizing the strengths possessed in the utilization of fishery resources based on local wisdom such as conducting fishery socialization / counseling.

Table 6. External Assessment Factors Analysis Summary

\begin{tabular}{|c|c|c|c|c|c|}
\hline \multicolumn{2}{|c|}{ Strategic Factor } & \multirow{2}{*}{$\frac{\text { Weight }}{0,23}$} & \multirow{2}{*}{ Rating } & \multirow{2}{*}{$\begin{array}{l}\text { Score } \\
1,15\end{array}$} & \\
\hline \multirow{3}{*}{ Opportunity } & Potential fish resources owned (O1) & & & & \\
\hline & Opportunities for work opportunities in other fields $(\mathrm{O} 2)$ & 0,15 & 4 & 0,62 & \\
\hline & The existence of supportive government policies (O3) & 0,23 & 5 & 1,15 & \\
\hline \multicolumn{2}{|c|}{ Total Opportunity } & & & & 2,92 \\
\hline Threats & $\begin{array}{l}\text { Bad weather or climate (T1) } \\
\text { Destructive fishing activities (Destructive and illegal fishing) } \\
\text { (T2) }\end{array}$ & $\begin{array}{l}0,15 \\
0,23\end{array}$ & $\begin{array}{l}2,50 \\
2,90\end{array}$ & $\begin{array}{l}0,38 \\
0,67\end{array}$ & \\
\hline Total Threat & & & & & $\mathbf{1 , 0 5}$ \\
\hline TOTAL & & 1,00 & & & 3,98 \\
\hline
\end{tabular}

The results of the analysis show that the main external factors are providing opportunities for the strategy (O1) the potential of fish resources owned is 1.15; (O3) opportunities from the existence of government policies so that they can strengthen the Hading-Hoba Mulung regulations by 1.15; (O2) employment opportunities in other fields such as processing catches are 0.62 . While the main threats, namely (T2) the existence of fishing activities that damage marine ecosystems by 0.67 ; (T1) bad weather and season by 0.38 . Opportunities have a greater value than threats, meaning that with opportunities they can minimize threats that will occur. The results of the IFAS and EFAS analysis show that the value of the policy on the use of fish resources based on local wisdom in Baranusa, namely Hading-Hoba Mulung, is still maintained and is the best policy chosen.

\section{Formulation of strategy to maintain the rules of the Oldest Hading-Hoba Mulung}

To formulate a strategy in maintaining the Hading-Hoba Mulung rule, the results of the analysis of internal factors and external factors, namely developing the strengths and opportunities to minimize the weaknesses, are presented in Table 7. 
Table 7. SWOT Matrix of alternative strategies to maintain the Hading-Hoba Mulung rule.

\begin{tabular}{|c|c|c|}
\hline \multirow{7}{*}{$\begin{array}{l}\text { Eksternal } \\
\text { Factor }\end{array}$} & Strength & Weakness \\
\hline & $\begin{array}{l}\text { 1. Having the Hading-Hoba } \\
\text { Mulung customary rules (S1) }\end{array}$ & $\begin{array}{l}\text { 1. Technology of fishing gear and } \\
\text { fishery business (W1) }\end{array}$ \\
\hline & $\begin{array}{l}\text { 2. Fishing activity is still profitable } \\
\text { (S2) }\end{array}$ & $\begin{array}{l}\text { 2. Limited access to marketing/sales of } \\
\text { catch (W2) }\end{array}$ \\
\hline & 3. Fisherman experience $(\mathrm{S} 3)$ & $\begin{array}{ll}\text { 3. Fishing business support facilities } \\
\text { (W3) }\end{array}$ \\
\hline & $\begin{array}{l}\text { 4. Abundance of high economic } \\
\text { fish resources in the Mulung area } \\
\text { (S4) }\end{array}$ & $\begin{array}{l}\text { 4. Weak institutional supervision of the } \\
\text { Baranusa indigenous people (W4) }\end{array}$ \\
\hline & & $\begin{array}{l}\text { 5. Lack of socialization/counseling on } \\
\text { fishing for fishermen (W5) }\end{array}$ \\
\hline & & 6. Conflict between fishermen (W6) \\
\hline Opportunity & S-O Strategy & W-O Strategy \\
\hline $\begin{array}{l}\text { 1. Potential fish } \\
\text { resources } \\
\text { owned }\end{array}$ & $\begin{array}{l}\text { 1. The existence of Hading-Hoba } \\
\text { Mulung regulations and } \\
\text { government policy support in } \\
\text { terms of the utilization of marine } \\
\text { resources and management can } \\
\text { provide job opportunities for } \\
\text { fishermen and the Baranusa } \\
\text { community. Strengthening the } \\
\text { Rules of Hading-Hoba Mulung } \\
\text { (S1 -S4, O1-O3) }\end{array}$ & $\begin{array}{l}\text { 2. By taking advantage of the } \\
\text { opportunities they have, better fishing } \\
\text { technology is needed so that the } \\
\text { catches of fishermen are more (W1- } \\
\text { O1) }\end{array}$ \\
\hline $\begin{array}{l}\text { 2. Opportunities } \\
\text { for work in } \\
\text { other fields }\end{array}$ & & $\begin{array}{l}\text { 3. Abundant catches are expected to } \\
\text { have adequate marketing facilities and } \\
\text { health insurance at the research site } \\
(\mathrm{W} 2, \mathrm{~W} 3, \mathrm{O} 2)\end{array}$ \\
\hline $\begin{array}{l}\text { 3. There are } \\
\text { supportive } \\
\text { government } \\
\text { policies }\end{array}$ & & $\begin{array}{l}\text { 4. There is a policy from the government } \\
\text { that supports and strengthens the } \\
\text { Hading-Hoba Mulung regulations, } \\
\text { socialization / counseling related to } \\
\text { the management of SDI based on local } \\
\text { wisdom that is owned so that there is } \\
\text { no conflict between fishermen } \\
\text { (W4,W5,W6,O3) }\end{array}$ \\
\hline
\end{tabular}

\begin{tabular}{rll}
\hline Threat & S-T Strategy \\
\hline 1. Bad weather & 5. & The Hading-Hoba Mulung \\
or climate & regulation also regulates the \\
& fishing time (Hoba) which is \\
adjusted to the weather or climate & so that fishermen are not worried \\
& and prohibits catching using \\
destructive fishing gear (S1-T1, \\
T2)
\end{tabular}

2. Destructive

and illegal

fishing

activities

\section{W-T Strategy}

. There is a policy from the government socialization / counseling related to the management of SDI based on local wisdom that is owned so that there is no conflict between fishermen W4,W5,W6,O3) $\mathrm{T} 2)$

6. Routine supervision is required, both from the Baranusa Customary Institution and the government (W4T2) 
From the results of the SWOT analysis, five alternative policies were obtained to maintain the Hading-Hoba Mulung rule in arresting activities in Baranusa, namely; (1) Strengthening of Hading-Hoba Mulung customary institutions, (2) Development of fishing technology, (3) Development of fishery support facilities (TPI, Ice Factory) and access to marketing, (4) Community empowerment through socialization/counseling on fisheries related to customary and government regulations , (5) Strengthening supervision activities by traditional institutions and the government in the Mulung area.

\section{CONCLUSIONS AND SUGGESTIONS}

\section{Conclusion}

The strategy to defend Hading-Hoba Mulung in Baranusa is as follows; (1) Strengthening of Hading-Hoba Mulung customary institutions, (2) Development of fishing technology, (3) Development of fishery support facilities (TPI, Ice Factory) and access to marketing, (4) Community empowerment through socialization/counseling on fisheries related to customary and government regulations , (5) Strengthening supervision activities by traditional institutions and the government in the Mulung area.

\section{Suggestion}

In connection with the conclusions of this study, several things are suggested, namely strategies to be recommended to the Baranusa customary council and the government in preparing tasks for each party involved in enforcing the Hading-Hoba Mulung rules, as well as collaborating with the Alor Regency Government to make a policy/regulation in the form of area marking. Mulung or giving symbols in the Mulung area so that there are no fishermen carrying out fishing activities in the Mulung area during Hading (sea closure), intensively introducing or socializing outside the Pantar Baran area in terms of introducing the Hading-Hoba Mulung rules.

\section{REFERENCES}

[1] [1]. Nikijuluw V.P.H, 2002. Rezim Pengelolaan Sumberdaya Perikanan. PT. Pustaka Cidesindo. Jakarta. Hal. 28.

[2] [2]. Dinas Perikanan Kabupaten Alor 2018. Laporan Tahunan Dinas Perikanan Kabupaten Alor.

[3] [3]. Hikmah, Ignasius, Defritus, 2018. Kearifan Lokal Hading Mulung Dalam Pengelolaan Sumberdaya Alam Wilayah Pesisir Dan Laut Di Desa Blangmerang Pantar Barat Kabupaten Alor. Skripsi. Universitas Nusa Cendana Kupang.

[4] [4]. Rangkuti F, 2014. Analisis SWOT Teknik Membelah Kasus Bisnis Jakarta: PT Gramedia Pustaka Utama.

[5] [5]. Afdol, Pulungan. M.S, Priambodo. B.B, 2012. Kebijakan dan Strategi Pengaturan Usaha Perikanan dan Pengelolaan Wilayah Pesisir Di Teluk Jakarta yang Mengacu pada Kearifan Lokal Masyarakat Nelayan Tradisional. Jurnal Hukum dan Pembangunan, Vol 42 (3) : 337 - 359.

[6] [6]. Ashari I.H, Saputri. D, Fitri. N.H.E, Susiana, Apriadi.T, 2018. Identifikasi Potensi Kearifan Lokal Masyarakat Pesisir Pulau Bintang dalam Upaya Konservasi Duyung (Dugong dugong, Muller 1776). Jurnal Pengkemas Maritim, Vol 1(1) : 28 - 36

[7] [7]. Aswani, Shakar, 2011. Socioelogical Approaches for Combining Ecosystem-Besad and Customary Management in Ocean. Journal of Marine Biology, Vol 10.(115).

[8] [8]. Bahtiar, 2012. Kearifan Lokal Orang Bajo dalam Pengelolaan Sumberdaya Laut. Jurnal MUDRA, Vol 27 (2) :178 - 185

[9] [9]. Bekti T.C, Melmambessy. E.H.P, Merly. S.L, 2019. Relationship of Perception and Communiy Participation in Management of Capture Fisheries Resources Based on Local Wisdom. Agricola Journal, Vol 9(1), pp 13-21.

\section{AUTHORS}

First Author - Luthfiah Usman, Master Program, Postgraduet School, Hasanuddin University, Makassar, Indonesia

Second Author - Achmar Mallawa, Faculty of Marine Sciences and Fisheries, Hasanuddin University, Makassar, Indonesia

Third Author - Mardiana Ethrawaty Fachry, Faculty of Marine Sciences and Fisheries, Hasanuddin University, Makassar, Indonesia

Correspondence Author - Email: luthfyahusman@gmail.com 